\title{
PENGARUH KONDISI GEOLOGI LINGKUNGAN TERHADAP POTENSI AIR TANAH DALAM DI KOTA MAKASSAR
}

\author{
Emi Prasetyawati Umar ${ }^{1 *}$, Alfian Nawir ${ }^{1}$, Jamaluddin $^{2}$, Aryadi Nurfalaq ${ }^{3}$ \\ ${ }^{1}$ Jurusan Teknik Pertambangan, Universitas Muslim Indonesia, Makassar, Indonesia \\ ${ }^{2}$ Geological Engineering, School of Geosciences, China University of Petroleum (East China), Qingdao, China \\ ${ }^{3}$ Teknik Informatika, Universitas Cokroaminoto Palopo \\ *Penulis koresponden. Alamat email: emiprasetyawati.umar@umi.ac.id
}

\begin{abstract}
Abstrak
Seiring dengan pesatnya perkembangan teknologi dan jumlah penduduk serta kemajuan pembangunan di segala aspek kehidupan, pemenuhan kebutuhan akan sumber daya air juga semakin meningkat. Salah satu aspek yang mempengaruhi potensi air tanah dalam adalah kondisi geologi suatu daerah. Berdasarkan hasil penelitian, penilaian geologi terhadap potensi air tanah dalam pada daerah penelitian tersebut terdiri dari morfologi pedataran bergelombang dan morfologi fluvial, satuan batuan terdiri satuan tufa, satuan aglomerat (dan breksi vulkanik) dan satuan aluvial, struktur geologi adalah kekar gerus. Airnya jernih dan memiliki nilai $\mathrm{pH}$ 7- 8 dan memenuhi syarat untuk kebutuhan air bersih.
\end{abstract}

Kata Kunci: Air tanah dalam, Geologi lingkungan, Kota Makassar.

\begin{abstract}
The rapid development in technology, increasing population growth rate and progressive development in all aspects of life, the need for drinking water resources is in also increasing. One prime aspect that affects the potential of deep groundwater is the geological condition of an area. Based on acquired results, the geological assessment for deep groundwater potential in the study area reveals a corrugated flat terrain morphology unit and fluvial morphology. Rock units consisting of tuff, agglomerate (and volcanic breccia) and alluvial unit, the geological structure is shear joint. The water is clear and having a $\mathrm{pH}$ value of 7-8 and meets the requirements for clean drinking water.
\end{abstract}

Keywords: Groundwater, Geologic Environment, Makassar City.

\section{Pendahuluan}

Kebutuhan sumber daya air di Kota Makassar semakin meningkat setiap saat baik digunakan untuk kebutuhan di rumah tangga, perkantoran, pusat perbelanjaan maupun industri (Nawir, 2018).

(C) 2019 Dept. of Geophysics Hasanuddin University
Perusahaan Daerah Air Minum (PDAM) adalah salah satu lembaga publik yang melayani masyarakat untuk pemenuhan air bersih di Kota Makassar. Tetapi masih ada sebagian masyarakat juga masih menggunakan air sumur gali untuk memenuhi kebutuhan sehari-hari yang akan digunakan untuk air minum, mencuci ataupun kebutuhan lainnya (Djaendi, 2002). 
Penting dan tingginya kebutuhan air tanah dalam (groundwater) di Kota Makassar, tidak diimbangi dengan adanya data yang cukup tentang sebaran dan kondisi potensi air tanah dalam (groundwater).

Potensi air tanah dangkal (shallow groundwater) untuk memenuhi kebutuhan air bersih di Kota Makassar bagian Timur tersusun atas satuan morfologi pedataran bergelombang, satuan batuan tufa, aglomerat dan struktur kekar yang memiliki nilai kisaran $\mathrm{pH}$ 7-8 serta warna air yang bening (Umar, 2018).

Kondisi air tanah Kota Makassar telah terintrusi oleh air laut, hal ini dapat dilihat oleh data geolistrik. Setiap akuifernya memberikan kondisi air tanah yang secara umum telah terintrusi dan air tanah yang terintrusi umumnya pada akuifer endapan pantai (Susilawati, 2009).

Salah aspek yang mempengaruhi kualitas air tanah dalam (groundwater) adalah kondisi geologi yang ada di Kota Makassar. Data geologi sangat penting terhadap kondisi dan keterdapatan air tanah dalam (groundwater) dalam upaya mengetahui dan mengevaluasi kualitas air. Hal inilah yang melatarbelakangi dilakukannya penelitian tentang hubungan kondisi geologi lingkungan terhadap potensi air tanah dalam di Kota Makassar.

\section{Metode Penelitian}

\section{Pengambilan Data Lapangan}

Penelitian ini menggunakan data primer sehingga pengambilan data dilakukan secara langsung ke lapangan untuk mengambil data. Pengambilan data di lapangan dilakukan dengan cara mengambil sampel air dan mengidentifikasi beberapa karakteristik fisik air.

\section{Analisis Data}

Analisis data pada penelitian ini terdiri dari analisis deskriptif - kuantitatif dan analisis sebaran dengan menggunakan analisis Sistem Informasi Geografis (SIG). Analisis deskriptif - kuantitatif meliputi analisis deskripsi data air tanah dalam, geomorfologi, litologi dan sebaran titik-titik sumur. Analisis geomorfologi dilakukan dengan pendekatan morfografi.

\section{Hasil dan Pembahasan}

Penilaian geologi terhadap potensi air tanah dalam (groundwater) didasarkan pada aspek geologi yaitu morfologi, batuan dan struktur struktur. Ditinjau dari aspek morfologi daerah penelitian tersusun oleh morfologi pedataran bergelombang, morfologi pedataran dan morfologi fluvial, aspek batuan tersusun oleh satuan tufa, satuan aglomerat dan satuan alluvial sedangkan ditinjau dari aspek struktur geologi berupa kekar.

Potensi air tanah di Kota Makassar pada umumnya terdiri dari 3 lapisan akuifer yang penyebarannya secara vertikal dan horizontal dikontrol oleh stratigrafi yang terdiri dari batuan Formasi Camba, Formasi Baturape Cindako dan Formasi Tonasa dengan kedalaman antara 30-225 meter, debit antara 0,5-15 liter/detik (Bachri, 2003).

\section{Satuan Morfologi}

Berdasarkan pendekatan morfografi dan morfometri, maka wilayah Kota Makassar dapat dikelompokkan menjadi tiga satuan, yaitu:

\section{a. Satuan Morfologi Pedataran Bergelombang}

Satuan ini menempati kurang lebih $40 \%$ dari seluruh luas wilayah penelitian. Satuan ini juga dapat dijumpai pada sebelah timur 
menyebar dari utara ke selatan daerah penelitian. Hasil pendekatan morfometri menunjukkan, persentase sudut lereng sekitar 3-7\%, beda tinggi sekitar 5-35 meter. Reliefnya berupa pedataran bergelombang. Kenampakan bentuk puncak sebagian berbentuk membulat akibat erosi yang cukup intensif dan pelapukan yang cukup tinggi.

Morfologi pedataran bergelombang memiliki karakteristik sifat fisik air sumur bor yaitu kedalaman sumur bor 30-75 meter, diameter pipa $3 \mathrm{~cm}$, pipa plastik, tahun pembuatan 2009 dan 2018, warna air berwarna bening, airnya tidak berbau, airnya jernih dan memiliki nilai $\mathrm{pH} 7$ dan 8 (tabel 1).

\section{b. Satuan Morfologi Pedataran}

Satuan ini menempati kurang lebih 50\% dari seluruh luas wilayah penelitian. Satuan ini dapat dijumpai pada sebelah barat menyebar dari utara ke selatan daerah penelitian. Hasil pendekatan morfometri menunjukkan persentase sudut lereng sekitar 0-2\%, beda tinggi sekitar 1-4 meter, reliefnya datar. Kenampakan bentuk puncak sebagian berbentuk datar akibat erosi yang cukup intensif dan pelapukan yang cukup tinggi.
Morfologi pedataran memiliki sifat fisik air sumur bor yaitu kedalaman sumur bor 20-30 meter, diameter pipa $3 \mathrm{~cm}$, pipa plastik, tahun pembuatan 2014 dan 2018, warna air berwarna bening, airnya tidak berbau, airnya jernih dan memiliki nilai $\mathrm{pH} 8$.

\section{c. Satuan Morfologi Fluvial}

Satuan ini menempati kurang lebih $10 \%$ dari seluruh luas wilayah penelitian. Satuan ini juga dapat dijumpai pada bagian utara, tengah dan selatan wilayah penelitian yang terdiri Sungai Maros, Sungai Tello dan Sungai Jeneberang yang mengalir dari arah timur ke barat

Morfologi fluvial secara umum memiliki kondisi fisik dan sifat fisik air sumur bor yaitu kedalaman sumur bor 6-40 meter, diameter pipa $3 \mathrm{~cm}$, pipa plastik, tahun pembuatan 1980 sampai 2017, warna air berwarna bening dan keruh, airnya tidak berbau dan berbau, airnya jernih dan keruh dan memiliki nilai $\mathrm{pH} 8$ dan 9.

\section{Batuan}

Satuan batuan pada daerah penelitian adalah tufa yang secara umum memiliki kondisi dan sifat fisik air sumur bor memiliki kedalaman sumur bor 30-75 meter, diameter pipa $3 \mathrm{~cm}$, pipa plastik, tahun pembuatan 2009 dan 2018, warna air berwarna bening,

Tabel 1. Sifat fisik air tanah

\begin{tabular}{ccccccc}
\hline \multirow{2}{*}{ No } & Sumur & \multicolumn{5}{c}{ Sifat } \\
\cline { 3 - 6 } 1 & A & Karna & Bau & Rasa & Kekeruhan & pH \\
2 & B & Bening & Tidak & Tawar & Keruh & 7 \\
3 & C & Bening & Tidak & Tawar & Jernih & 8 \\
4 & D & Bening & Tidak & Tawar & Jernih & 8 \\
5 & E & Bening & Tidak & Tawar & Jernih & 7 \\
6 & F & Bening & Tidak & Tawar & Jernih & 7 \\
7 & G & Bening & Tidak & Tawar & Jernih & 7 \\
8 & H & Bening & Tidak & Tawar & Jernih & 7 \\
\hline
\end{tabular}


airnya tidak berbau, airnya jernih dan memiliki nilai pH 7 dan 8 (Gambar 1).

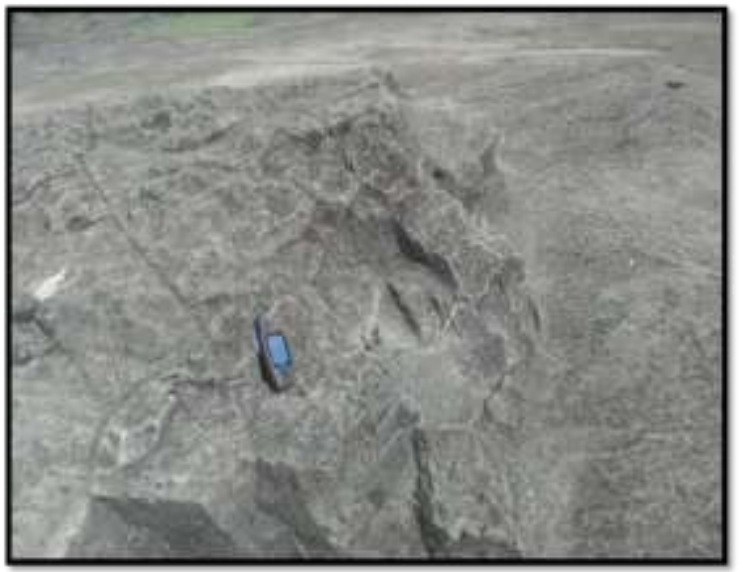

Gambar 1. Satuan tufa dengan kondisi air nilai pH 7, warna air bening, tidak berbau dan rasanya tawar.

Satuan aluvial secara umum memiliki kondisi dan sifat fisik yaitu kedalaman sumur bor 6-40 meter, diameter pipa $3 \mathrm{~cm}$, pipa plastik, tahun pembuatan 1980 sampai 2017, warna air berwarna bening dan keruh, airnya tidak berbau dan berbau, airnya jernih dan keruh dan memiliki nilai $\mathrm{pH} 8$ dan 9 (Gambar 2).

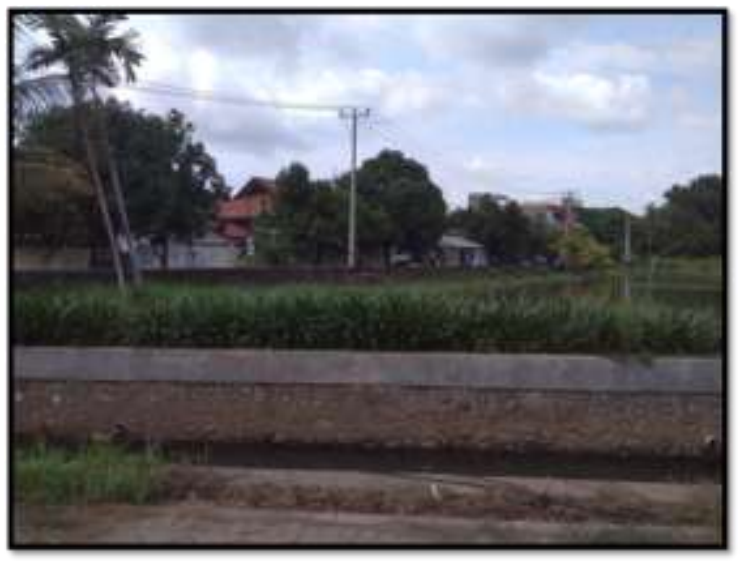

Gambar 2. Satuan aluvial dengan kondisi air nilai pH 9, warna air keruh, berbau dan rasanya payau.

\section{Struktur Geologi}

Struktur geologi yang berkembang di daerah penelitian berupa kekar gerus (shear joint) memiliki karakteristik pada kedalaman sumur bor 30-75 meter, diameter pipa $3 \mathrm{~cm}$, pipa plastik, tahun pembuatan 2009 dan 2018, warna air berwarna bening, airnya tidak berbau, airnya jernih dan memiliki nilai pH 7 dan 8 (Gambar 3).

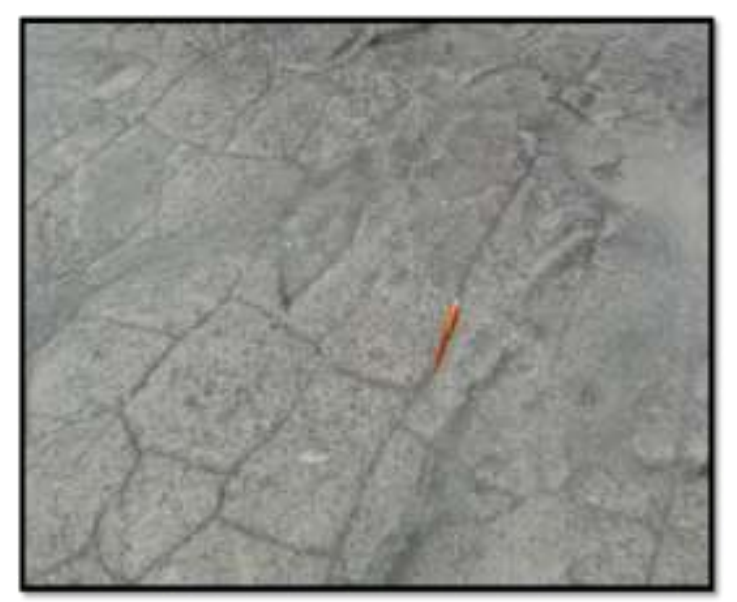

Gambar 3. Kekar gerus (shear joint) dengan kondisi air nilai pH 8, warna air bening, tidak berbau dan rasana tawar.

Satuan aluvial secara umum memiliki kondisi dan sifat fisik kedalaman sumur bor yaitu 6-40 meter, diameter pipa $3 \mathrm{~cm}$, pipa plastik, tahun pembuatan 1980 sampai 2017, warna air berwarna bening dan keruh, airnya tidak berbau dan berbau, airnya jernih dan keruh dan memiliki nilai $\mathrm{pH} 8$ dan 9.

Karakteristik air tanah dalam sebagai kategori air bersih yaitu terdapat pada satuan batuan tufa yang memiliki nilai $\mathrm{pH}$ 7-8, warna air bening, tidak berbau dan rasanya tawar dan secara fisik air tanah dalam yang tidak memenuhi syarat air bersih ditinjau dari aspek kesehatan terdapat pada satuan aluvial dengan nilai $\mathrm{pH}$ 9, warna air kecoklatan, berbau, airnya keruh dan rasanya payau.

Gambar 4 menunjukkan peta sebaran air tanah dalam Kota Makassar yang memenuhi syarat sebagai air bersih. Peta tersebut menunjukkan bahwa sebaran air tanah dalam yang memenuhi syarat sebagai air bersih berada pada bagian timur Kota 
Makassar yang terdapat pada satuan batuan aglomerat (dan breksi vulkanik) dan tufa. Satuan batuan tufa ini menempati luas atau $40 \%$ dari luas keseluruhan daerah penelitian. Satuan batuan ini menempati daerah sebelah barat menyebar dari arah utara ke selatan daerah penelitian. Sedangkan satuan batuan aglomerat sekitar $10 \%$ dari luas keseluruhan daerah penelitian. Penyebaran satuan breksi vulkanik ini menempati lokasi di bagian timur daerah penelitian. Satuan ini tersingkap dengan baik dalam kondisi segar di sekitar Sudiang, Mangga Tiga dan BTP.

\section{Kesimpulan}

Kesimpulan dari penelitian ini adalah morfologi daerah penelitian terdiri dari morfologi pedataran bergelombang, morfologi pedataran dan morfologi fluvial. Satuan batuan daerah penelitian terdiri satuan tufa, satuan aglomerat (dan breksi vulkanik) dan satuan alluvial yang memiliki sifat air dengan nilai $\mathrm{pH} \mathrm{7-8,} \mathrm{warna} \mathrm{air}$ bening, tidak berbau dan rasanya tawar sehingga memenuhi syarat untuk kebutuhan air bersih.

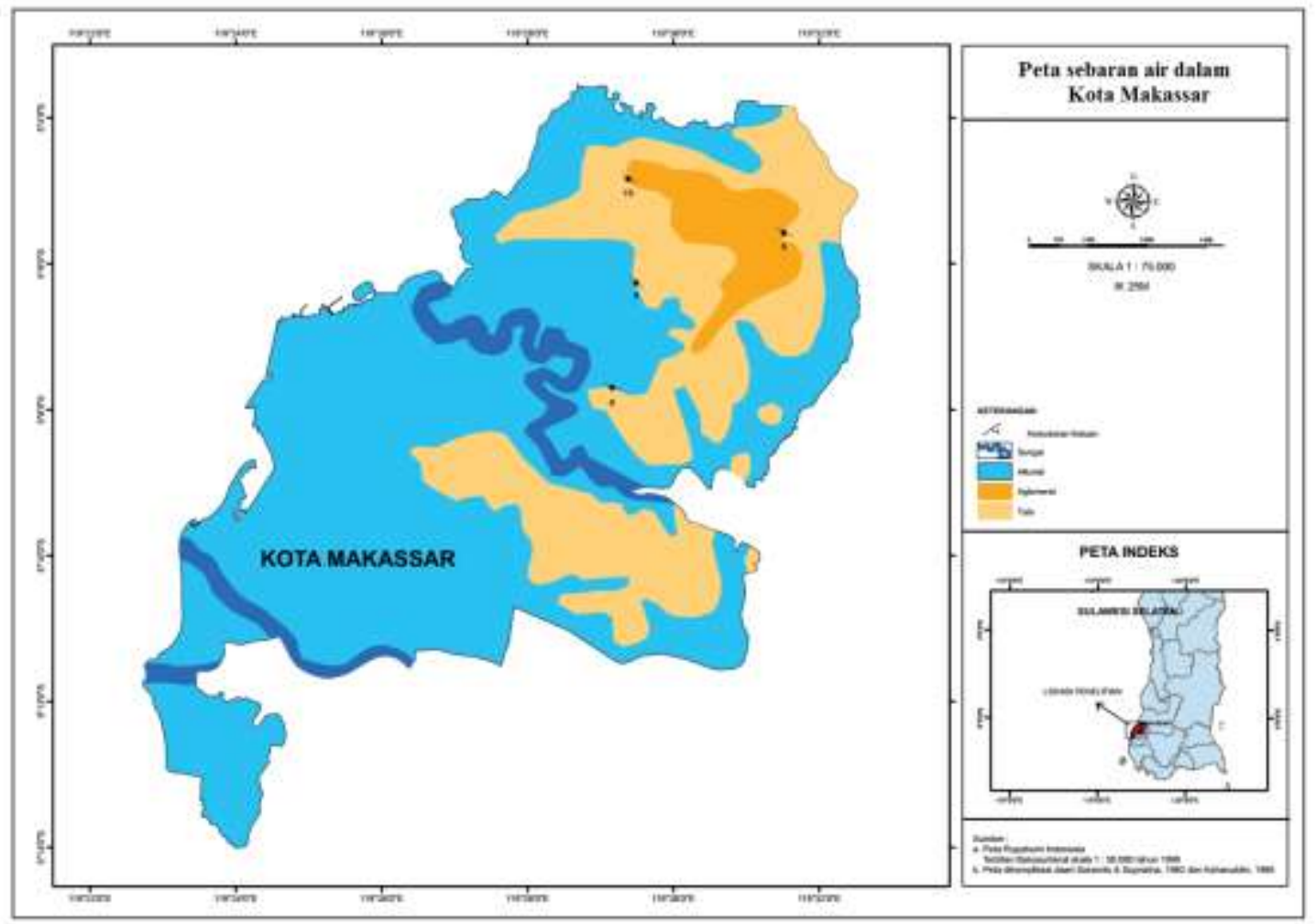

Gambar 4. Peta sebaran air tanah dalam yang memenuhi syarat sebagai air bersih

\section{Daftar Pustaka}

Bachri, Syamsul. 2003. Optimalisasi Pemanfaatan Air Tanah Dalam Kawasan Industri Makassar. Universitas Hasanuddin.

Djaendi. 2002. Pengelolaan Air Tanah Berwawasan Lingkungan. Direktorat Tata Lingkungan Geologi \& kawasan
Pertambangan Umum, Bandung. Nawir, Alfian dan Umar, Emi Prasetyawati. 2018. Analisis Akuifer Kota Makassar. Jurnal Geomine. 6(1), 3033.

Susilawati. 2009. Sistem Akuifer Air Tanah Dangkal Kota Makassar, Provinsi 
Sulawesi Selatan. Universitas Hasanuddin.

Umar, Emi Prasetyawati. dan Nawir, Alfian. 2018. Potensi Air Tanah Dangkal dalam Pemenuhan Kebutuhan Air Bersih Kota Makassar. Jurnal Geomine. 6(2), 91-95. 